\title{
Influence of Land Use Patterns on Evapotranspiration and Its Components in a Temperate Grassland Ecosystem
}

\author{
Yuzhe Li, ${ }^{1,2}$ Jiangwen Fan, ${ }^{1}$ Zhongmin Hu, ${ }^{3}$ Quanqin Shao, ${ }^{1}$ \\ Liangxia Zhang, ${ }^{1,2}$ and Hailing Yu ${ }^{1,2}$ \\ ${ }^{1}$ Key Laboratory of Land Surface Pattern and Simulation, Institute of Geographical Sciences and Natural Resources Research, \\ Chinese Academy of Sciences, Beijing 100101, China \\ ${ }^{2}$ University of Chinese Academy of Sciences, Beijing 100049, China \\ ${ }^{3}$ Key Laboratory of Ecosystem Network Observation and Modeling, Synthesis Research Center of Chinese Ecosystem Research Network, \\ Institute of Geographic Sciences and Natural Resources Research, Chinese Academy of Sciences, Beijing 100101, China
}

Correspondence should be addressed to Jiangwen Fan; fanjw@igsnrr.ac.cn

Received 18 September 2014; Accepted 9 December 2014

Academic Editor: Jinwei Dong

Copyright (C) 2015 Yuzhe Li et al. This is an open access article distributed under the Creative Commons Attribution License, which permits unrestricted use, distribution, and reproduction in any medium, provided the original work is properly cited.

To better understand variation in response of components of ecosystem evapotranspiration (ET) to grassland use differences, we selected three typical land use patterns in a temperate steppe area: grazed steppe (G), steppe with grazers excluded (GE), and steppe cultivated to cropland (C). ET was divided into its components evaporation (E) and canopy transpiration (T) using herbicide and a chamber attached to a portable infrared gas analyzer (Li-6400). The results indicated that daily water consumption by ET in G was $3.30 \mathrm{~kg} \mathrm{~m}^{-2} \mathrm{~d}^{-1}$; compared with G, ET increased significantly in GE at $13.4 \%$ and showed a trend of $6.73 \%$ increase in C. Daily water consumption by $\mathrm{E}$ increased $24.3 \%$ in GE relative to $\mathrm{G}$, and $\mathrm{C}$ showed $20.2 \%$ more than GE. At 0.46 , E/ET in C was significantly higher than $\mathrm{G}$ at 0.35 . Air temperature and the vapor pressure deficit were closely correlated with variation in diurnal ET, E, and T. The leaf area index (LAI) was also positively correlated with daily ET and E varied among grassland use patterns and explained variation in E/ET (81\%). Thus, variation in LAI strongly influences the overall magnitude of ecosystem ET and the composition of its components under different grassland use patterns.

\section{Introduction}

Large-scale changes in land use are strongly connected to global climate change [1-3]. In recent years, changes in land use patterns in large areas of grassland in Northern China [4] have altered surface vegetation cover [5] and, as a result, significantly influenced the ecosystem and regional environment [6]. Grazed steppe covers the majority of grassland area in the European-Asian continent [7]. In Northern China, grazing by livestock has long been the major anthropogenic influence on the temperate grassland ecosystem. In recent years, however, grassland destruction by sandstorms has increased environmental protection awareness and government input for grassland restoration in China, resulting in a rapid increase in steppe area where grazing is excluded [1]. In contrast, in response to crop-planting limits and the need for economic benefit, a large grassland area in the pastoralfarming ecotone of the steppe in China has been converted to cropland [8]. By altering vegetation, original soil structure, and microclimate, changes in grassland use may affect overall ecosystem evapotranspiration (ET), as well as its components soil surface evaporation by vapor loss (E) and canopy vapor consumption by transpiration ( $\mathrm{T}$ ). These processes contribute to carbon uptake [9].

Water is a critical limiting factor in arid and semiarid grassland area in Northern China and influences productivity and regional climate $[10,11]$. ET is related to a number of ecosystem processes, including photosynthesis, soil moisture, and latent heat transfer [12] and plays an important role in global energy and water cycles [8]. The magnitude and dynamics of ET differ with changes in vegetation traits, meteorological conditions, and soil characteristics [13]. Therefore, 
it is important to investigate how change in grassland use patterns in the Northern China steppe has altered local vapor budget and water balances, thereby influencing natural ecological functions in these grasslands $[14,15]$ and impacting regional climate.

Previous work on ET has been conducted primarily using the eddy covariance system [15-17] and the lysimeter [18]. The eddy covariance system can record ET automatically over long durations, but, because of its whole-ecosystem scale [19], it is difficult to distinguish differences in water flux among local sites. This problem can be resolved by using a chamber attached to a portable infrared analyzer [2022], which is more suitable for measuring flux of adjacent plots. Thus it can be used to determine the influence of the land use type on water exchange within an ecosystem. In addition, few previous studies have correctly divided ET into soil evaporation (E) and transpiration (T) [8], resulting in difficulty uncovering underlying mechanisms of variation in ET $[23,24]$. However, with a fine treatment such as clipping, portable infrared gas analyzers measured the contribution of E to total ET [25]. Measuring the components of ET (E and $\mathrm{T}$ ) is key not only to understand mechanisms underlying variation in ecosystem ET with grassland use patterns [23] but also to help resolve uncertainties in modeling simulation of ET or latent heat and thereby to increase simulation precision $[25,26]$.

We used herbicide rather than clipping and removing the vegetation to more accurately divide ecosystem ET into canopy $\mathrm{T}$ and surface $\mathrm{E}$, as killing the vegetation with herbicide leaves the structure intact, largely maintaining the original level of shading. Specifically, we aimed to (i) understand the effect of the varied grassland use patterns on the components of ET and the daily vapor transfer between the ecosystem and the atmosphere and (ii) investigate the mechanisms underlying changes in ET and its composition among different grassland use patterns in the steppe.

\section{Materials and Methods}

2.1. Study Area. This study was conducted on Stipa grandis, a dominant grass of the temperate steppe, at Xilinhot, Inner Mongolia, Northern China $\left(43^{\circ} 32^{\prime} 24.06^{\prime \prime} \mathrm{N}, 116^{\circ} 33^{\prime} 41.76^{\prime \prime} \mathrm{E}\right.$, elevation $1250 \mathrm{~m}$ ). The study site is located at $500 \mathrm{~km}$ north to Beijing and is considered as an important sand source of Beijing (Figure 1). Between 1982 and 2004, mean annual temperature was $0.6^{\circ} \mathrm{C}$, and mean monthly temperature ranged from $-21.4^{\circ} \mathrm{C}$ (January) to $18.5^{\circ} \mathrm{C}$ (July) [20]. Mean annual precipitation was $350 \mathrm{~mm}$, mainly falling from June to August during the main growth period. The weather is mainly dry and windy, and the soils are chestnut or chernozem soil. Data of the main meteorological parameters during the experimental period (August 2012) are shown in Figure 2.

2.2. Observation Design. Three types of land use in adjacent areas were selected for study: grazed steppe $(G)$, steppe with grazers excluded (GE), and steppe cultivated to cropland (C). $G$ is a typical steppe that has been grazed by sheep and horses for more than 20 years. GE is steppe where herbivores

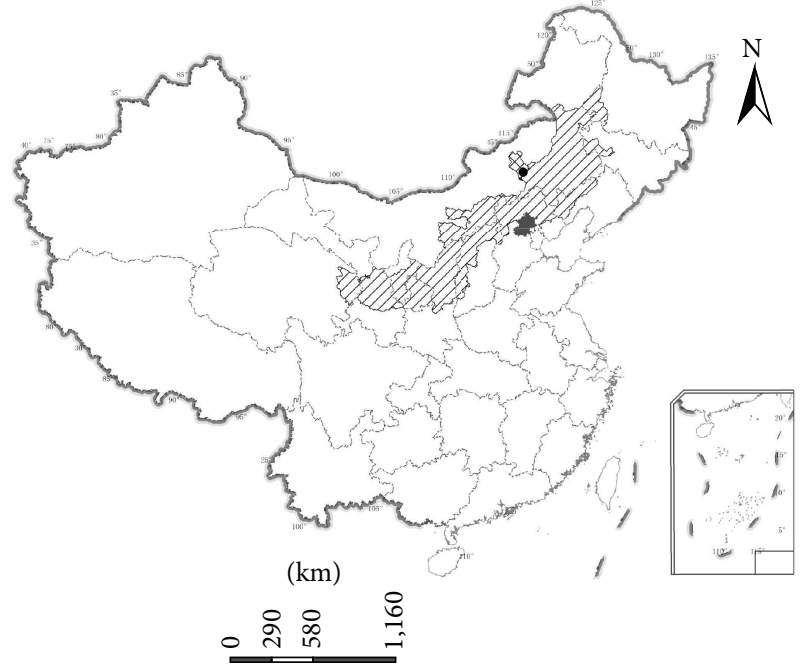

- Study site

Xilinhot

ZZ Pastoral-farming ecotone $\square$ Beijing

FIGURE 1: The location of the study area and the pastoral-farming ecotone in Northern China.

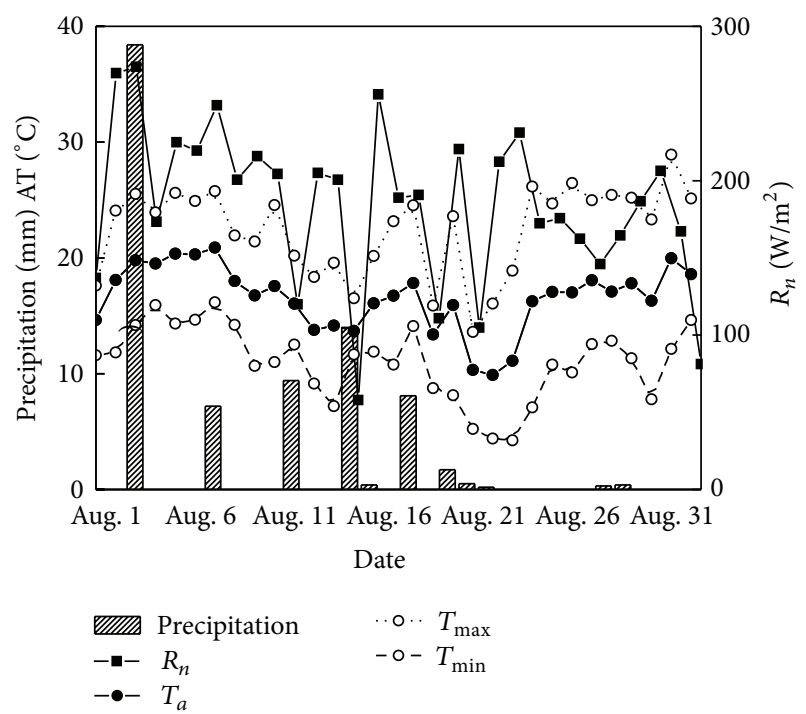

FIGURE 2: Daily precipitation, air temperature $\left(T_{a}\right.$, daily mean; $T_{\max }$, daily maximum; $T_{\min }$, daily minimum) and net radiation $\left(R_{n}\right)$ during the experimental period from 1 August to 31 August 2012 in a typical temperate steppe at Xilinhot, Inner Mongolia.

have been excluded since 1979 and a large amount of plant litter remains on the ground. The original land use and community structure of $\mathrm{C}$ were similar to $\mathrm{G}$ until 5 years prior to the study, when the land was cultivated for wheat cropping. No irrigation is applied to cropped areas. Organic manure was applied prior to crop planting, and $240 \mathrm{~kg} \mathrm{hm}^{-2}$ effective fertilizer ( $\mathrm{N} 110 \mathrm{~kg} / \mathrm{ha}, \mathrm{P}_{2} \mathrm{O}_{5} 70 \mathrm{~kg} / \mathrm{ha}$, and $\mathrm{K}_{2} \mathrm{O}$ $60 \mathrm{~kg} / \mathrm{ha}$ ) was applied in two applications during crop growth. At the center of the grazed steppe (G) $\left(43^{\circ} 32^{\prime} 24.06^{\prime \prime} \mathrm{N}\right.$, $\left.116^{\circ} 33^{\prime} 41.76^{\prime \prime} \mathrm{E}\right)$, an eddy covariance system was set up to measure the water, carbon, and heat exchange between the 
TABLE 1: Microclimate characteristics of land use types (LT) and vegetation cover treatments (TR).

\begin{tabular}{|c|c|c|c|c|}
\hline $\mathrm{LT} / \mathrm{Tr}$ & $\mathrm{ST}\left({ }^{\circ} \mathrm{C}\right)$ & SM (\%) & $\operatorname{AT}\left({ }^{\circ} \mathrm{C}\right)$ & VPD \\
\hline \multicolumn{5}{|l|}{ G } \\
\hline DS & $20.68 \pm 0.81^{\mathrm{a}}$ & $21.98 \pm 0.81^{\mathrm{a}}$ & $21.84 \pm 1.00^{\mathrm{a}}$ & $1.72 \pm 0.14^{\mathrm{a}}$ \\
\hline $\mathrm{CL}$ & $20.94 \pm 0.37^{\mathrm{a}}$ & $21.34 \pm 0.78^{\mathrm{a}}$ & $21.89 \pm 1.02^{\mathrm{a}}$ & $1.78 \pm 0.16^{\mathrm{a}}$ \\
\hline $\mathrm{CK}$ & $19.82 \pm 0.71^{\mathrm{ab}}$ & $21.91 \pm 0.79^{\mathrm{a}}$ & $21.79 \pm 1.02^{\mathrm{a}}$ & $1.68 \pm 0.13^{\mathrm{a}}$ \\
\hline \multicolumn{5}{|l|}{ GE } \\
\hline DS & $17.69 \pm 0.55^{\mathrm{bc}}$ & $26.10 \pm 0.56^{\mathrm{bc}}$ & $21.71 \pm 1.05^{\mathrm{a}}$ & $1.76 \pm 0.16^{\mathrm{a}}$ \\
\hline $\mathrm{CL}$ & $18.47 \pm 0.32^{\mathrm{b}}$ & $22.83 \pm 0.67^{\mathrm{ab}}$ & $22.01 \pm 1.08^{\mathrm{a}}$ & $1.81 \pm 0.16^{\mathrm{a}}$ \\
\hline $\mathrm{CK}$ & $17.25 \pm 0.46^{\mathrm{c}}$ & $24.41 \pm 0.30^{\mathrm{b}}$ & $21.63 \pm 0.97^{\mathrm{a}}$ & $1.68 \pm 0.14^{\mathrm{a}}$ \\
\hline \multicolumn{5}{|l|}{ C } \\
\hline DS & $18.76 \pm 0.26^{\mathrm{abc}}$ & $27.09 \pm 0.51^{c}$ & $23.15 \pm 0.89^{\mathrm{a}}$ & $1.29 \pm 0.14^{\mathrm{a}}$ \\
\hline $\mathrm{CL}$ & $20.55 \pm 0.37^{\mathrm{a}}$ & $24.23 \pm 0.44^{\mathrm{b}}$ & $23.39 \pm 0.90^{\mathrm{a}}$ & $1.28 \pm 0.14^{\mathrm{a}}$ \\
\hline $\mathrm{CK}$ & $18.17 \pm 0.42^{\mathrm{bc}}$ & $26.33 \pm 0.14^{\mathrm{c}}$ & $23.09 \pm 0.86^{\mathrm{a}}$ & $1.22 \pm 0.13^{\mathrm{a}}$ \\
\hline
\end{tabular}

Different letters in the same column indicate statistical differences at $P<0.05$. ST, soil temperature; SM, soil moisture; AT, air temperature; VPD, vapor deficit; $\mathrm{CK}$, control; DS, dry standing; $\mathrm{Cl}$, clipped.

ecosystem and atmosphere. The flux tower was positioned more than $800 \mathrm{~m}$ from the boundaries of GE and C.

The study area was set up using a randomized block design. Within each type of land use, there were four replicate blocks ( $3.5 \mathrm{~m} \times 3.5 \mathrm{~m}$ with $5 \mathrm{~m}$ space between blocks). Four $1 \mathrm{~m} \times 1 \mathrm{~m}$ plots were randomly arranged within each block, with $1.5 \mathrm{~m}$ between plots. Two weeks before observation began, one plot in each block (DS) was randomly selected and sprayed with herbicide ( $41 \%$ glyphosate, diluted with water 150 times). All vegetation in these plots withered in 2 days, but the canopy remained standing and dry throughout the observation period. Another plot in each block (CL) was chosen in which the aboveground tissue was removed by clipping, following the procedure used in previous studies $[20,23]$. The third randomly selected plot in each block served as the control plot (CK) to which no further treatment was administered. The fourth plot was used for destructive sampling to determine the community characteristics of each block, including above/belowground biomass, leaf area index (LAI), and soil properties.

For determination of ET, we found that the herbicide method (DS) resulted in shading and surface roughness more similar to the control plots (CK) than the commonly used clipping method $[20,23](\mathrm{CL})$, providing more realistic evaporation and microclimate conditions. Thus, the DS method provides a more accurate determination of ecosystem $\mathrm{E}$, consequently improving the accuracy of separating $\mathrm{T}$ from ET. This method assumes that transpiration in herbicidesprayed plots (DS) was completely suppressed by withering of all living plant tissues. Thus, vapor exchange in DS plots would mainly come from earth surface evaporation (E). Plant transpiration $(\mathrm{T})$ was calculated by subtracting $\mathrm{E}$ in the DS treatment from ET in the control. Of the different observational methods to partition the components of soil evaporation (E) and canopy transpiration ( $\mathrm{T}$ ) from ecosystem ET, our approach appears to be the most accurate, as it disturbs the original environmental conditions the least (Table 1) and avoids the influence of air advection or large eddies $[15,18,23]$.
2.3. Vapor Flux Measurements. Two weeks before observations began, a square metal base $\operatorname{rim}(50 \mathrm{~cm} \times 50 \mathrm{~cm}$ in area, $10 \mathrm{~cm}$ in height with $3 \mathrm{~cm}$ aboveground) was installed in each of the three types of observed plot (CK, CL, and DS) for the measurement of the vapor exchange rate. The vapor exchange rate was determined by a cubic chamber $(50 \mathrm{~cm} \times 50 \mathrm{~cm} \times 50 \mathrm{~cm})$ attached to an infrared gas analyzer (IRGA, LI-6400, LiCor, Lincoln, NE, USA). When measurements commenced, thirty consecutive recordings of vapor concentrations were taken for each placed chamber at $1 \mathrm{~s}$ intervals during $30 \mathrm{~s}$ periods. $\mathrm{H}_{2} \mathrm{O}$ flux rates were calculated from the time courses of changing concentrations. The fluxes of $\mathrm{E}$ were directly determined in the treatments of DS, and the fluxes of ET were determined in CK plots. This staticchamber method has been used and validated in previous studies [23]. One temperature probe at the center measured air temperature (AT) and another pushed into the soil aside the chamber measured soil temperature (ST) at $5 \mathrm{~cm}$ depth. The soil moisture (SM) was measured with a portable soil moisture device (TDR100, Spectrum, Plainfield, IL, USA).

The water exchange ET and E rates were calculated based on the formula $[20,23]$

$$
F_{h}=\frac{1000 V P_{\mathrm{av}}}{R S\left(T_{\mathrm{av}}+273\right)} \times \frac{d c}{d t},
$$

where $F_{h}$ is $\mathrm{H}_{2} \mathrm{O}$ flux $\left(\mathrm{mmol} \mathrm{m} \mathrm{s}^{-2} \mathrm{~s}^{-1}\right.$, positive $F_{h}$ values represent ecosystem vapor release and negative represent vapor condensation); $V$ is the chamber volume $\left(\mathrm{m}^{3}\right), P_{\mathrm{av}}$ is the average pressure $(\mathrm{kPa}), R$ is the ideal gas constant $\left(8.314 \mathrm{~J} \mathrm{~mol}^{-1} \mathrm{~K}^{-1}\right), S$ is the surface area covered by chamber $\left(\mathrm{m}^{2}\right), T_{\mathrm{av}}$ is the average temperature $\left({ }^{\circ} \mathrm{C}\right)$ during the measurement, and $d c / d t$ is the slope of linear least squares regression of $\mathrm{H}_{2} \mathrm{O}$ concentration by time.

The transpiration rate $(\mathrm{T})$ was calculated by the difference between ET and E:

$$
\mathrm{T}=\mathrm{ET}-\mathrm{E} \text {. }
$$

Observations were conducted on clear sunny days during the peak in live grassland biomass (August). Observations 
TABLE 2: Community characteristics of the three land uses.

\begin{tabular}{|c|c|c|c|}
\hline Use pattern & Grazing (G) & Grazing exclusion (GE) & Cultivation to cropland (C) \\
\hline Constructive species & Stipa grandis & Stipa grandis & Triticum aestivum \\
\hline Average cover (\%) & $56.3 \pm 2.4^{\mathrm{a}}$ & $95.0 \pm 2.0^{\mathrm{b}}$ & $93.8 \pm 1.25^{\mathrm{b}}$ \\
\hline Average height $(\mathrm{cm})$ & $14.75 \pm 0.95^{\mathrm{a}}$ & $56.25 \pm 5.54^{\mathrm{b}}$ & $89.0 \pm 1.29^{c}$ \\
\hline Soil organic carbon (g/kg) & $11.98 \pm 1.73^{\mathrm{a}}$ & $15.10 \pm 1.89^{b}$ & $19.77 \pm 1.05^{\mathrm{c}}$ \\
\hline Soil bulk density $\left(\mathrm{g} / \mathrm{cm}^{3}\right)$ & $1.63 \pm 0.02^{\mathrm{a}}$ & $1.37 \pm 0.06^{\mathrm{b}}$ & $1.29 \pm 0.02^{\mathrm{b}}$ \\
\hline Leaf area index (LAI) & $0.42 \pm 0.03^{\mathrm{a}}$ & $0.68 \pm 0.05^{\mathrm{a}}$ & $1.33 \pm 0.13^{\mathrm{b}}$ \\
\hline Total biomass $\left(\mathrm{kg} * \mathrm{~s}^{-1}\right)$ & $2.04 \pm 0.14^{\mathrm{a}}$ & $3.01 \pm 1.38^{\mathrm{b}}$ & $1.02 \pm 0.06^{\mathrm{c}}$ \\
\hline Above/underground biomass (\%) & $3.73 \pm 0.20^{\mathrm{a}}$ & $5.95 \pm 0.29^{\mathrm{b}}$ & $64.50 \pm 2.24^{\mathrm{c}}$ \\
\hline C4 total biomass (\%) & $32.98 \pm 1.70^{\mathrm{a}}$ & $6.10 \pm 2.26^{\mathrm{b}}$ & $0^{c}$ \\
\hline Litter fall $\left(\mathrm{g} / \mathrm{m}^{2}\right)$ & $1.60 \pm 0.55^{\mathrm{a}}$ & $84.81 \pm 4.47^{\mathrm{b}}$ & $10.98 \pm 1.00^{\mathrm{c}}$ \\
\hline Species abundance $(S)$ & $7.25 \pm 0.63^{\mathrm{a}}$ & $4.00 \pm 0.41^{\mathrm{b}}$ & $2.25 \pm 0.25^{\mathrm{c}}$ \\
\hline
\end{tabular}

Mean \pm standard; the different letters in the same row signify significant changes between them $(P<0.05)$.

were conducted continuously through the day at 1-hour intervals over 12 days. During each day, measurements were taken within one land use type to ensure similar weather conditions within an ecosystem to maintain comparability of data. Thus each land use or ecosystem type (C, G, and GE) had 4 replicate days of observation.

Daily vapor exchange (E, T, and ET) in each of the three ecosystems was calculated from the $\mathrm{H}_{2} \mathrm{O}$ flux rates obtained with the portable infrared gas analyzers using the following equation:

$$
\text { Daily water exchange }=\int_{0: 00}^{24: 00} F_{h} * 18 * 10^{-6}\left(\mathrm{~kg} \mathrm{H}_{2} \mathrm{O}\right) \text {, }
$$

where $F_{h}$ is the $\mathrm{H}_{2} \mathrm{O}$ flux $\left(\mathrm{mmol} \mathrm{m}^{-2} \mathrm{~s}^{-1}\right.$, positive $F_{h}$ values represent ecosystem vapor release and negative values represent vapor uptake).

2.4. Measurement of Community Characteristics. Species composition, average height, and plant cover were measured in the 12 observational plots in each of the three different land uses of steppe (G, GE, and C). Aboveground biomass was measured with the clipping method, and underground biomass was measured with the root drill method [4]. LAI was measured using the method proposed by Miao et al. [8].

2.5. Data Analysis. Origin 8.0 was used for figure drawing and SPSS 12.0 was used for data analysis. Three one-way ANOVAs followed by Duncan tests were used to analyze the differences of ecosystem microclimates and community and soil characteristics among the three land uses. Paired $t$-tests compared the diurnal dynamics of ecosystem vapor exchange within each of the three types of land use. One-way ANOVAs and Duncan tests analyzed the mean daily accumulated E, $\mathrm{T}$, and ET among the three land uses. Linear regression analysis compared the consistency of ET measurements between the eddy covariance system and the portable infrared chamber method. Linear regression analysis was used to evaluate the relationships of ET and its composition E/ET on environmental factors.

\section{Results}

3.1. Microclimate and Community Characteristics of Land Use Types. Soil temperature of $\mathrm{G}$ was significantly higher than that of GE. At 2.5\% less than GE and $4.42 \%$ less than C, G had the lowest soil moisture (Table 1). Land use also significantly affected soil condition but had little effect on aerial microclimate factors including temperature and VPD. Clipping did not cause marked microclimate change in G blocks, but, in GE and C blocks, CL plots had increased temperatures and reduced soil moisture relative to CK plots (Table 1). There were no significant differences of microclimate factors between paired DS and CK plots.

Land use pattern substantially influenced the grassland community characteristics. Total biomass in $\mathrm{C}$ and $\mathrm{G}$ was significantly lower than in GE (Table 2). The proportion of the aboveground biomass and biomass of $\mathrm{C} 4$ plants also varied significantly among the three types of land use (Table 2). Litter fall was significantly higher in GE than in G or C. The LAI was the lowest in G, with 300\% higher LAI in C and $62 \%$ higher in GE (Table 2). The influence of land use on soil properties was visible in the soil organic carbon (Table 2, $P<0.05)$ and bulk density.

3.2. Components of ET in Response to Different Land Uses. The daily dynamics of E, T, and ET among the different land uses of grassland steppe were generally represented by a unimodal curve that peaked around midday (Figures 3(a)3(c)), although a minor midday depression in T (Figure 3(b)) may have driven a similar trend in ET (Figure 3(c)).

GE and $\mathrm{C}$ both tend to increase the average daily ET of the grazed steppe, which was $3.30 \mathrm{~kg} \mathrm{~m}^{-2} \mathrm{~d}^{-1}$ (Figure 4). Cultivation significantly increased ecosystem ET 13.4\% over that of grazed steppe $\left(3.74 \mathrm{~kg} \mathrm{~m}^{-2} \mathrm{~d}^{-1} ; P<0.05\right)$, whereas the change in grazing exclusion $\left(3.52 \mathrm{~kg} \mathrm{~m}^{-2} \mathrm{~d}^{-1} ; P<0.05\right)$ was not significant.

Land use type did not significantly affect $\mathrm{T}(P>0.05)$ but increased rates of $\mathrm{E}$ relative to $\mathrm{C}$ in $\mathrm{G}$ and GE $(24.3 \%$ and $40.2 \%$, resp. $)(P<0.05)$. Consequently, variation in $\mathrm{E}$ was the driving cause of differences in ET among the three grassland uses (Figures 3(a) and 4(a)). The proportion of 


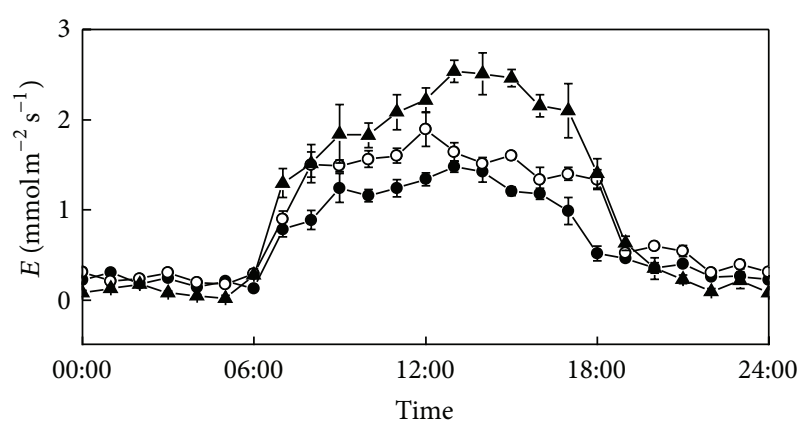

(a)

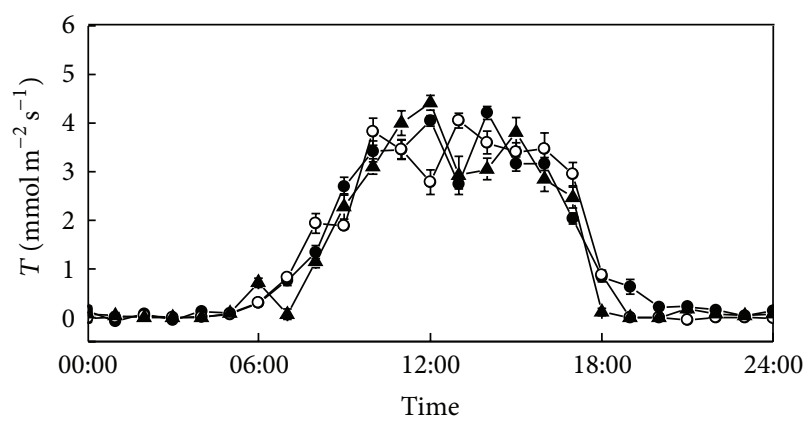

(b)

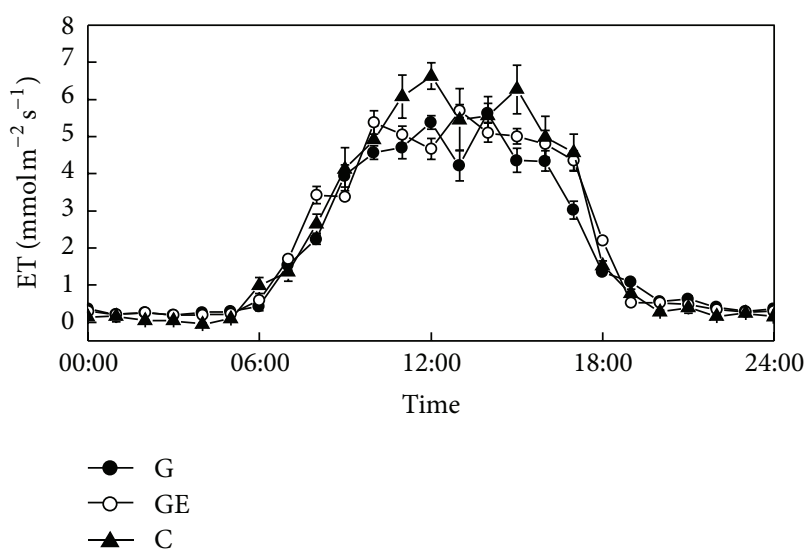

(c)

FIGURE 3: Daily dynamics of vapor exchange composition of different land uses during the peak growing period. (a) Evaporation (E); (b) transpiration (T); (c) evapotranspiration (ET). Error bar was $1 \mathrm{SE}$. G; grazing; GE, grazing excluded; C, crop.

evaporation to total vapor consumption (E/ET, Figure 4) of C was significantly increased in comparison with $\mathrm{G}(P<0.05)$.

3.3. Relationships between Components of ET and Microclimate Factors. The components (E, T) of total ecosystem vapor consumption (ET) were significantly correlated with AT and VPD among different grassland uses (Figures 5(a)5(f), $P<$ 0.001). AT explained a large proportion of the variance in ET among the types of steppe land uses (Figure 5(a), 81-83\%).

Variation among the grassland uses in sensitivity of the components of ET to microclimate factors was reflected by

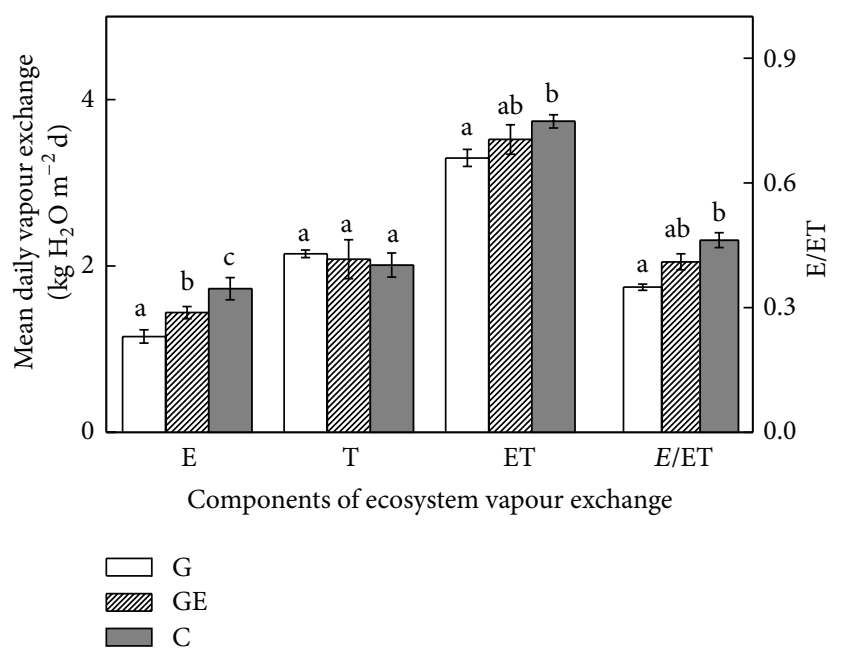

Figure 4: Compositions of mean daily ecosystem vapor consumption (E, T, ET, and E/ET) for different steppe grassland uses. The values represent the daily mean values (means $\pm 1 \mathrm{SE}$ ) in the peak growing period. Different letters in each bar group indicate significant difference $(P<0.05)$. G, grazing; GE, grazing excluded; C, crop.

differences in their regression slopes. The sensitivity of $\mathrm{T}$ to VPD (Figure 5(f), 0.14-0.16) and AT (Figure 5(c), 1.201.31) did not differ substantially among the three land uses. However, crop cultivation increased the sensitivity of E to AT by $160 \%$ relative to grazed steppe (Figure 5(b)). Moreover, in GE and C plots, the slope of the regression of E to VPD was 1.4 and 3.3 times that of grazed plots, respectively (Figure 5(e)). The differential sensitivity of E led to a variable overall response of ET to VPD and AT among the three grassland uses. ET responded more strongly to AT (Figure 5(a)) and VPD (Figure $5(d)$ ) in cultivated plots than grazed or grazer exclusion plots.

\subsection{Relationships between Components of ET and Community} Traits. Variation in each of the community traits (aboveground biomass, LAI, soil bulk density, and mean soil moisture) was significantly linearly correlated with mean daily vapor consumption by E and ET among different patterns of grassland use (Figure 6, all $P<0.01$ ). In particular, a large proportion of the variance in both ET and E were explained by LAI (78-87\%) and soil moisture (89-90\%). Trends of linear correlation between ET and biomass, LAI, soil bulk density, and soil moisture were consistent with those of E. There were no significant relationships between $\mathrm{T}$ and aboveground biomass, LAI, soil bulk density, or soil moisture (Figure 6, $P>0.05$ ).

3.5. Mechanisms Underlying Variance in E/ET among Steppe Grassland Uses. Linear correlations between mean daily vapor consumption and mean daily E/ET were significant for both $\mathrm{E}$ (Figure 7(a), $P<0.001$ ) and $\mathrm{T}$ (Figure 7(b), $P<0.05)$, though the relationship was stronger for $\mathrm{E}$. Additionally, mean daily water consumption by E explained 


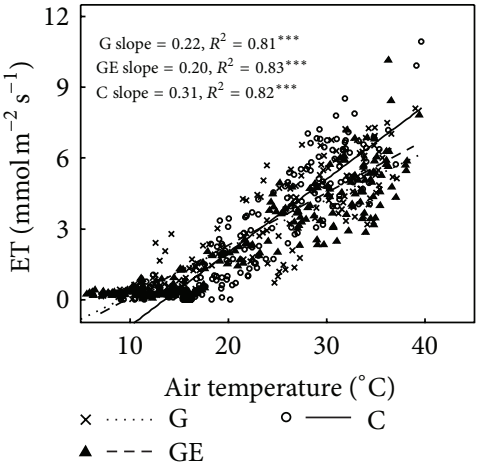

(a)

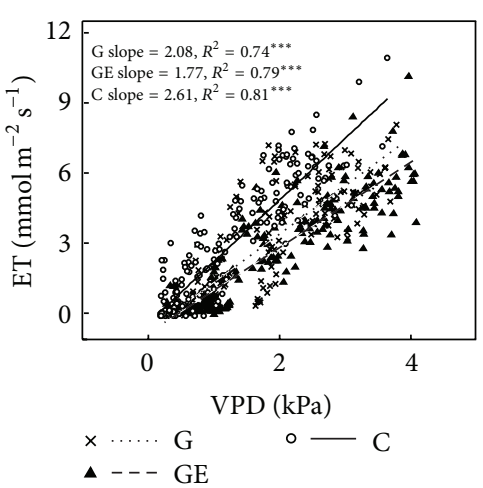

(d)

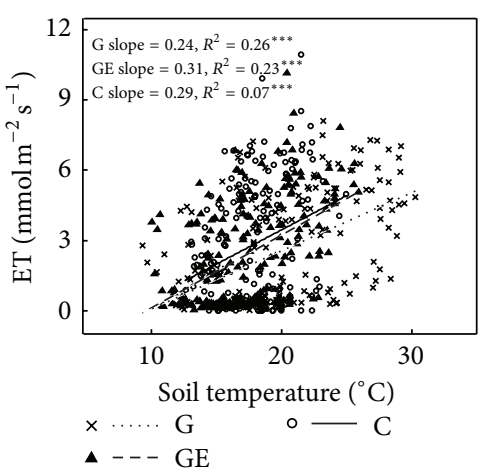

(g)

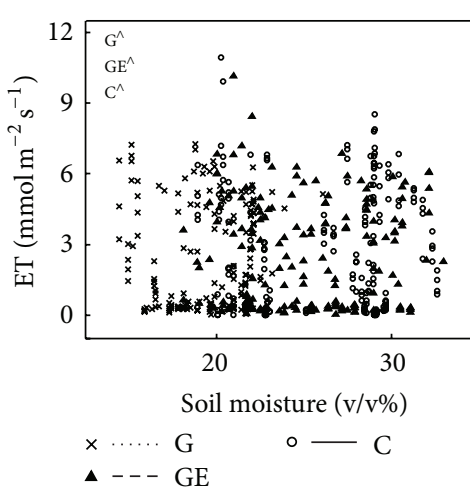

(j)

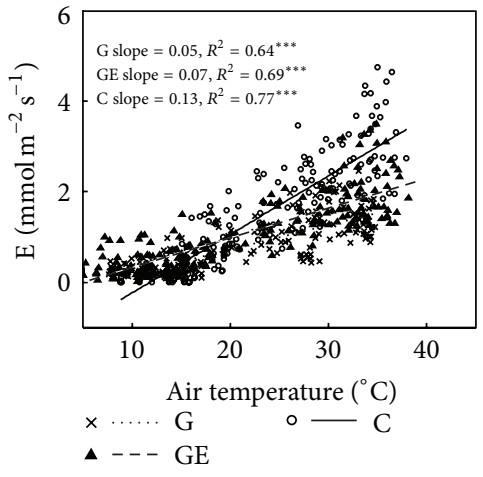

(b)

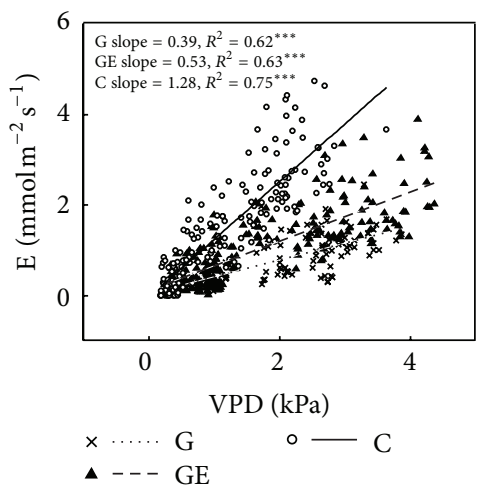

(e)

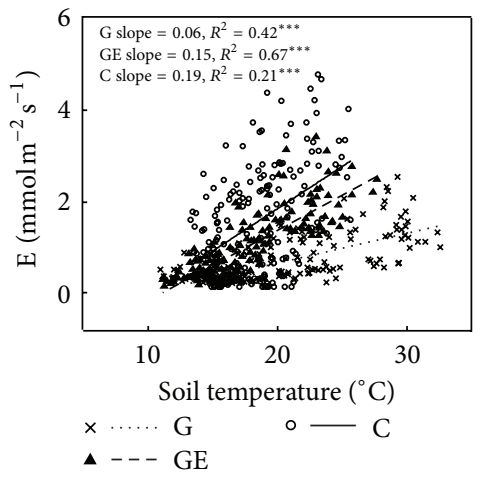

(h)

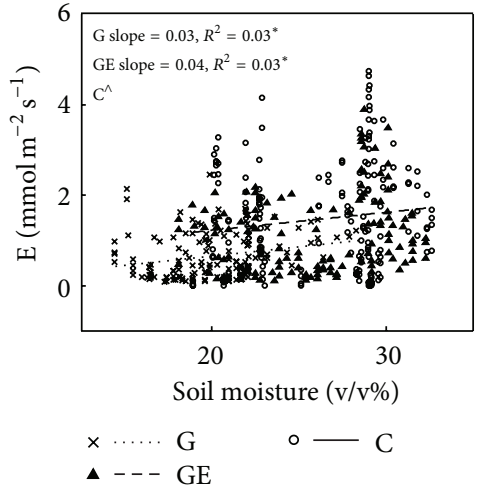

(k)

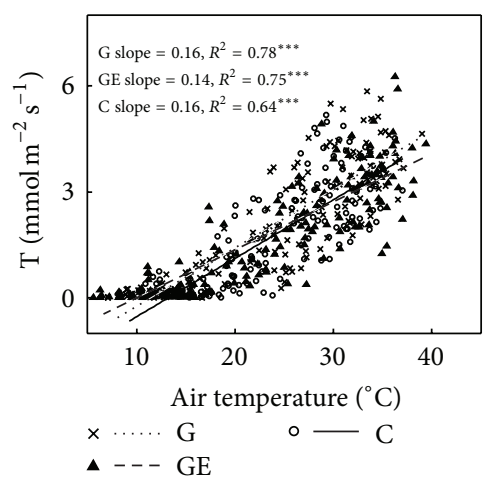

(c)

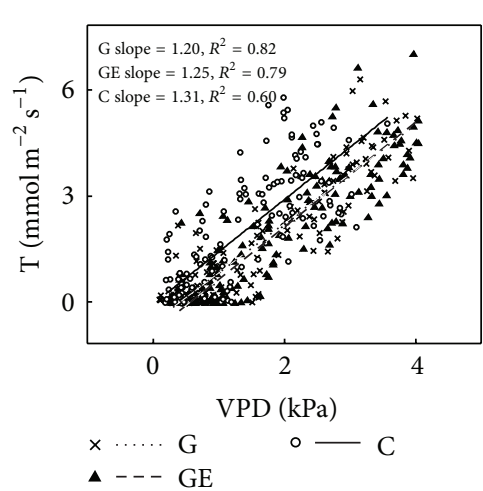

(f)

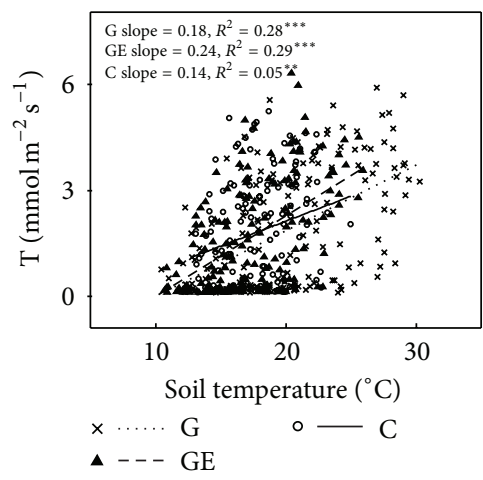

(i)

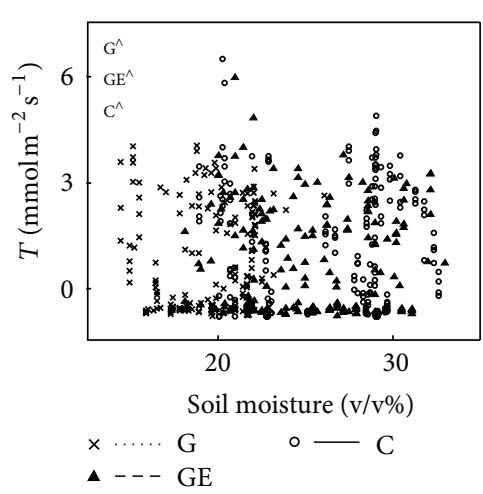

(1)

FIGURE 5: Relationships between microclimate factors (AT, VPD, ST, and SM) on vapor exchange rates (ET, E, and T) across the three land uses of steppe. $R^{2}$ and probabilities of regressions are shown; ${ }^{\wedge} P>0.05 ;{ }^{*} P<0.05 ;{ }^{* *} P<0.01$; ${ }^{* * *} P<0.001$. G, grazing; GE, grazing excluded; C, crop. 


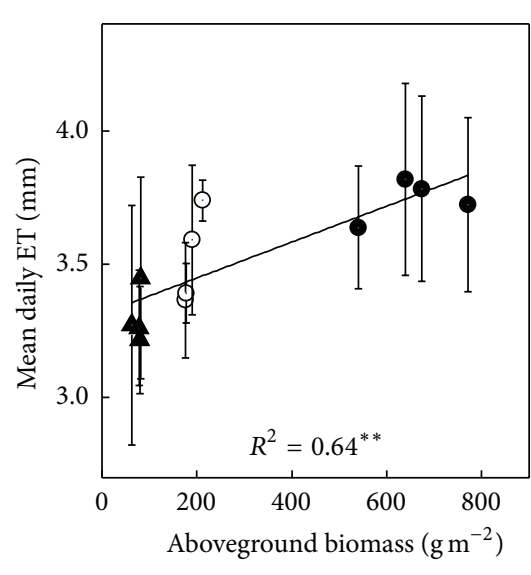

- $C$

O GE

$\Delta G$

(a)

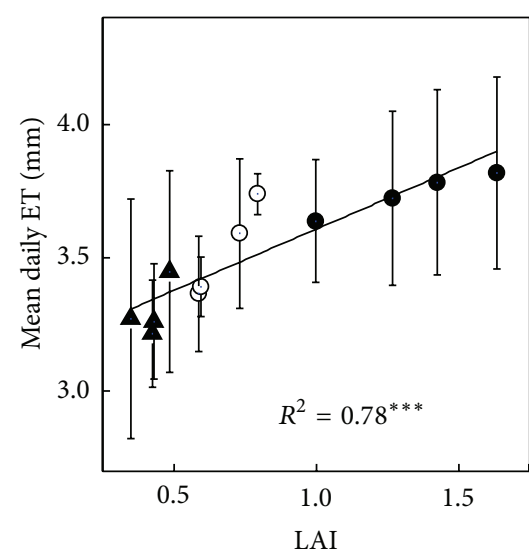

- $C$

$\mathrm{OGE}$

$\Delta G$

(d)

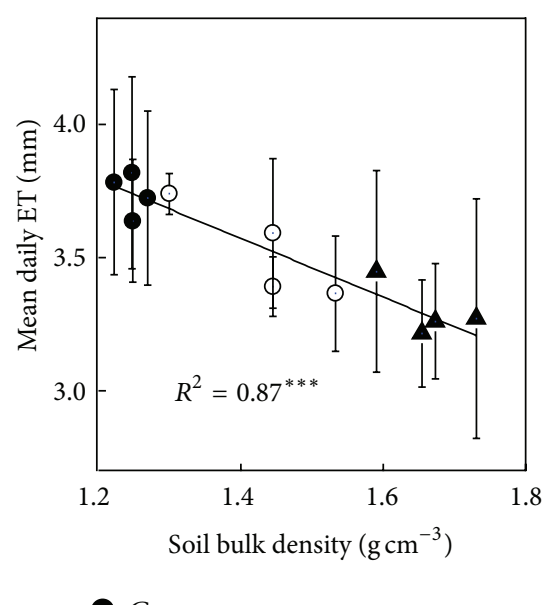

- $C$

O GE

$\Delta G$

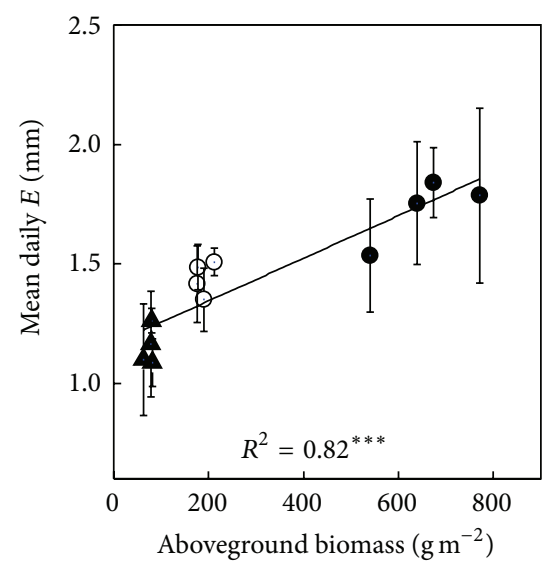

- $C$

$O$ GE

$\Delta G$

(b)

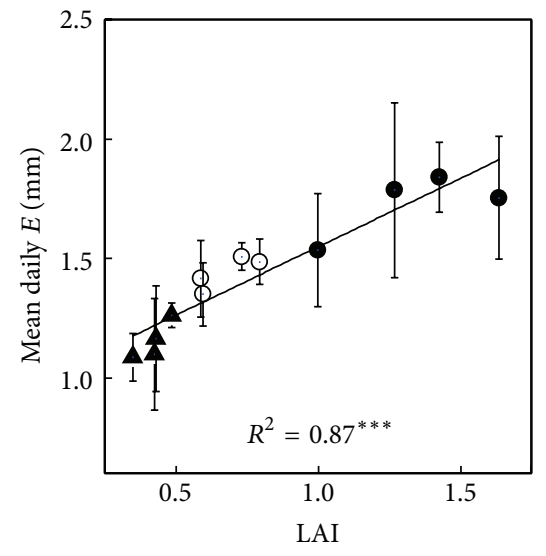

- $C$

$\mathrm{OGE}$

$\Delta G$

(e)

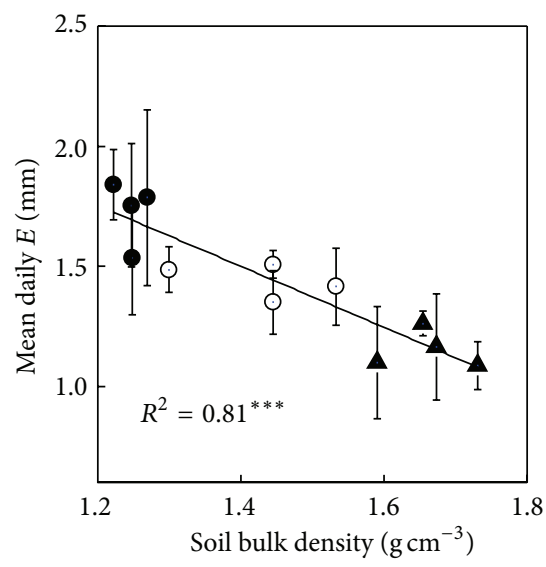

- $C$

O GE

$\Delta G$

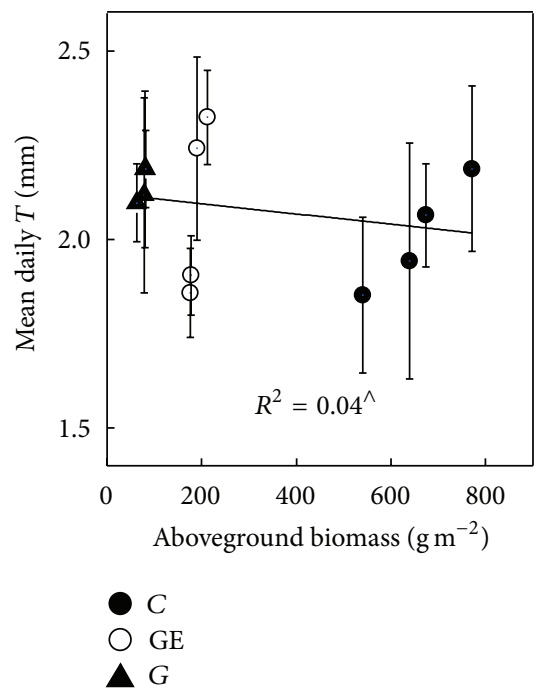

(c)

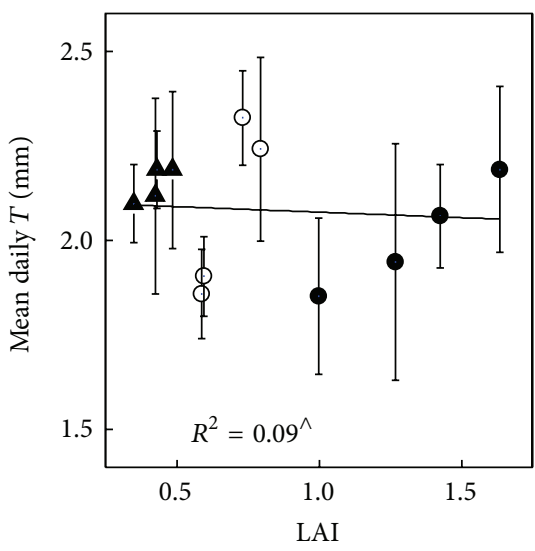

- $C$

$\bigcirc \mathrm{GE}$

$\Delta G$

(f)

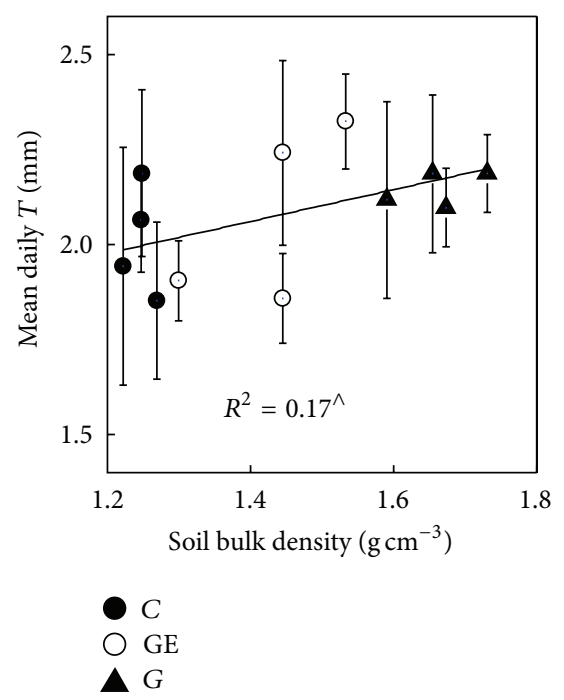

(i)

(h)

Figure 6: Continued. 


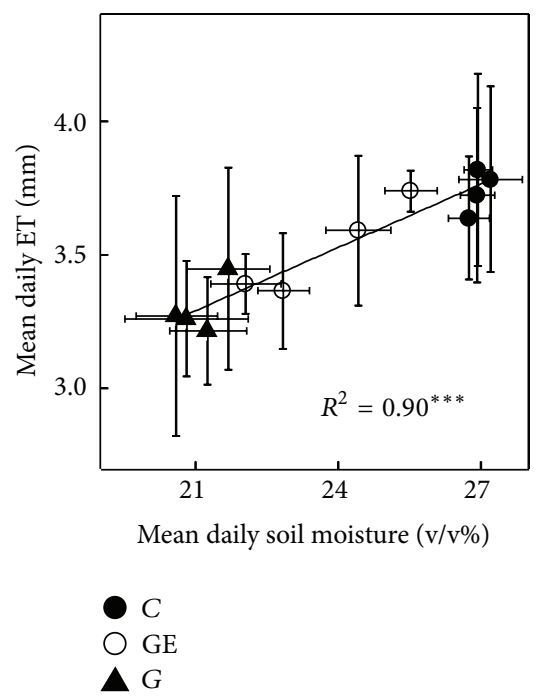

(j)

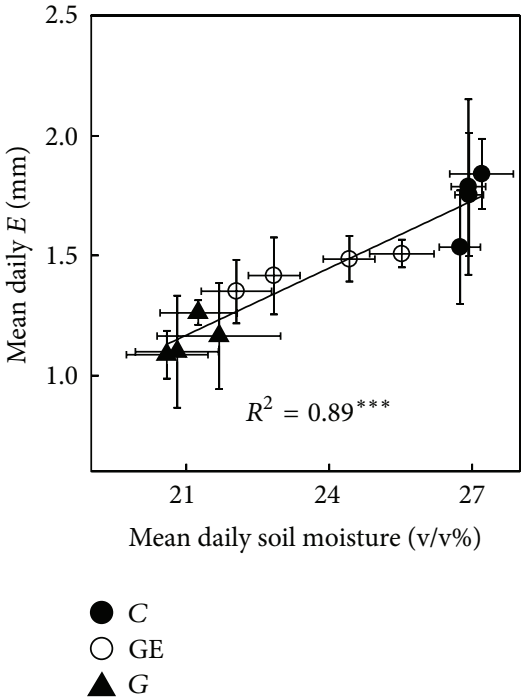

$(\mathrm{k})$

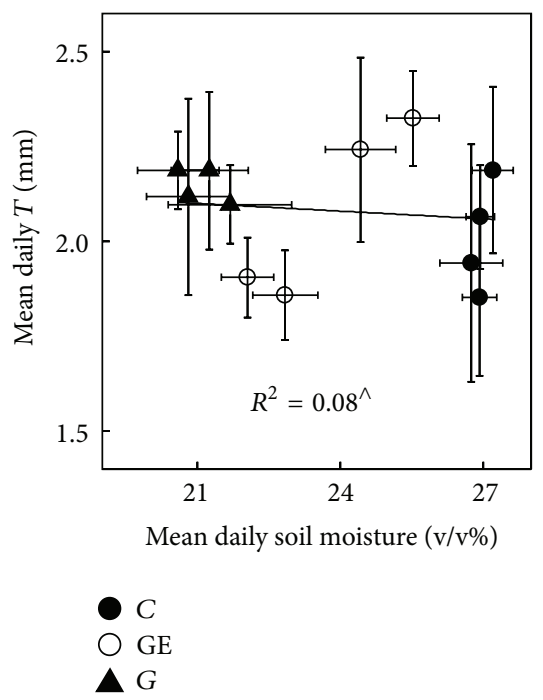

(l)

FIGURE 6: Relationships between mean daily water consumption components (E, T, and ET) on aboveground biomass, leaf area index (LAI), soil bulk density, and soil moisture across the three different steppe land uses. Error bar in WUE was 1SE. $R^{2}$ and probabilities of regressions are shown; ${ }^{\wedge} P>0.05 ;{ }^{*} P<0.05 ;{ }^{* *} P<0.01 ;{ }^{* * *} P<0.001$. G, grazing; GE, grazing excluded; $\mathrm{C}$, crop.

three times more variance in E/ET than $\mathrm{T}$ (90\% versus $30 \%$ ). LAI (Figure 7(c)) and soil moisture (Figure 7(d)) were also positively correlated with E/ET, while the relationship between LAI and soil moisture depended on the level of LAI. When LAI was less than 1 , soil moisture was positively linearly correlated with LAI, but values of LAI larger than 1 did not stimulate corresponding increases in soil moisture (Figure 7(e)).

\section{Discussion}

4.1. Effect of Grassland Use Types on the Components of ET. Because ecosystem ET takes away heat from the earth surface through latent heat transport, variation in ET with different grassland uses may alter the energy budget and consequently affect the regional climate [8]. ET rates determined by converted latent heat measurements taken by the eddy covariance system were highly correlated with ET rates measured using the chamber method (Figure $8, P<$ 0.01 ), confirming the reliability of chamber-measured vapor exchange rates. In addition, our measurements of ET rates in the three different patterns of grassland use were comparable to relevant previous work and modeled data for adjacent areas $[1,8,26]$. Though the chamber-measured ET rates were highly correlated with eddy covariance methods, yet there are uncertainties, which are caused by the measurement devices, in ET compositions (E and T). The certain deviation in this method is due to the chamber. Since the chamber blocked the natural wind, this should cause underestimate of surface $\mathrm{E}$ and lead to a certain overestimate of T rates.

Previous research has shown that different land uses can significantly change community structure $[27,28]$, soil properties $[29,30]$, and microclimate conditions [31-33], which may be correlated with ecosystem vapor exchange
[34-37]. Consistent with this previous work [8, 24], our study demonstrated that cultivation and exclusion of grazing increased ET, the total vapor consumption of an ecosystem. Our examination of the individual components of ET revealed that it was evaporation (Figure $4, P<0.05$ ), not transpiration (Figure 4, $P>0.05$ ), that caused the variance in ET among the different land uses of the steppe (Figure 4, Figure 6). Although few previous experimental studies in grassland ecosystems have separated ET into E and T [25], a study doing so in an agricultural ecosystem also found that changes in E were more important than those in $\mathrm{T}$ in driving patterns of ET, among different crop species [24].

Despite the suggestion of previous large-scale studies including cross regional simulations $[26,37]$ and long-term observations [8] that vegetation with higher LAI should have lower E/ET, our findings corroborated those of another regional study [24], showing that E/ET was higher in land use types with higher LAI in adjacent areas (Figure 4). These contrasting results demonstrate that the components of ET may respond variably to increases in LAI depending on the spatial and temporal scale of the study. The positive relationship between E/ET and LAI in our study (Figure 7(c)) may be owing to the shading effect of redundant LAI. During the peak growing season, when LAI reaches its maximum, an individual plant in any grassland use type has redundant leaves which are shaded by those newer and higher leaves of its own. Thus, in those land uses with higher LAI, the increase of LAI just enhanced the shading; ineffective leaves would not contribute substantially to an increase in canopy T. In contrast, increased shading in communities with a larger LAI would result in higher soil moisture. In arid and semiarid areas, where water supply is a limiting factor of $\mathrm{E}$ [26], increased soil moisture would stimulate higher rates of surface E. 


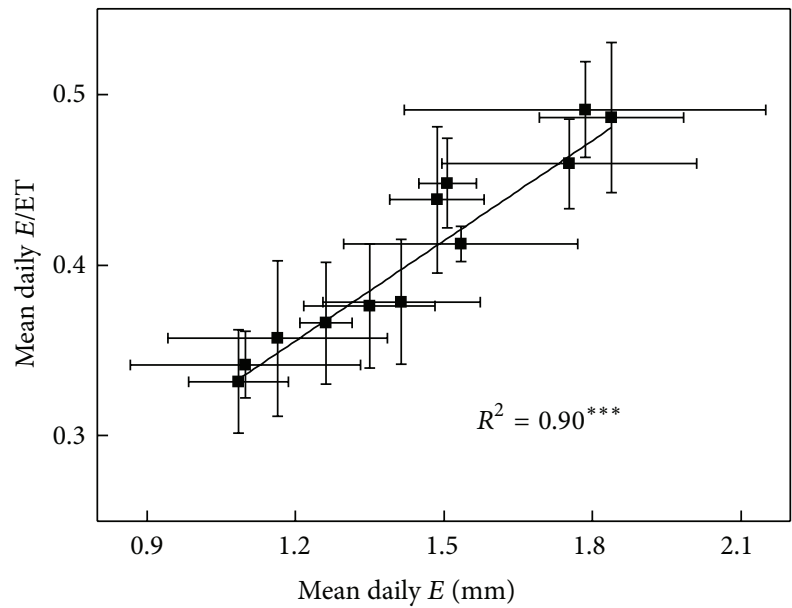

(a)

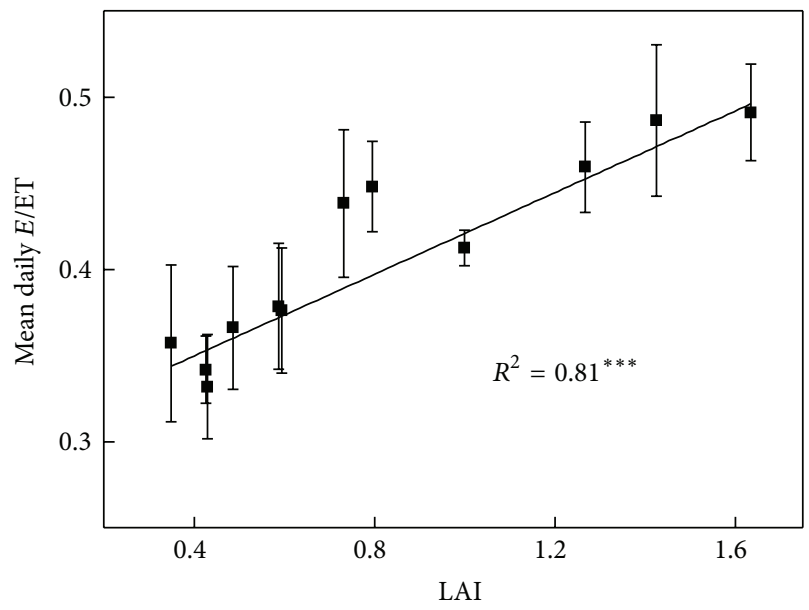

(c)

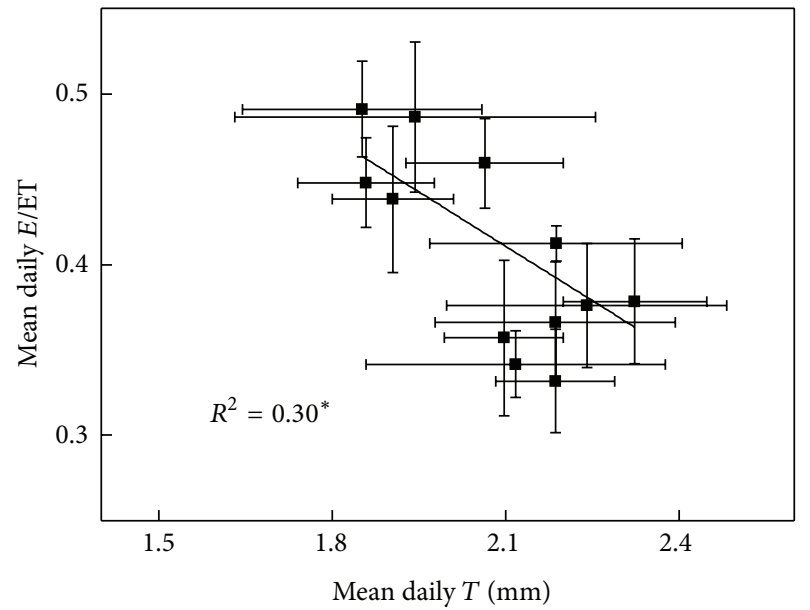

(b)

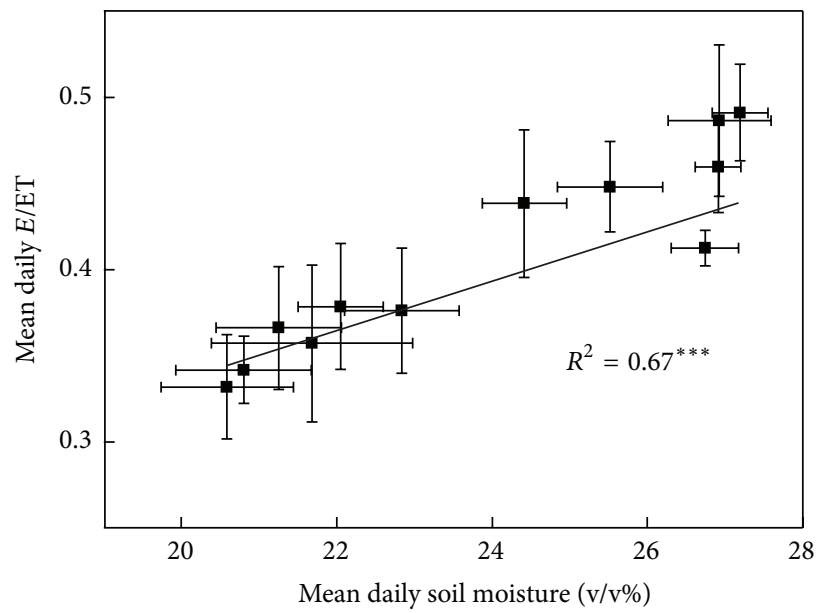

(d)

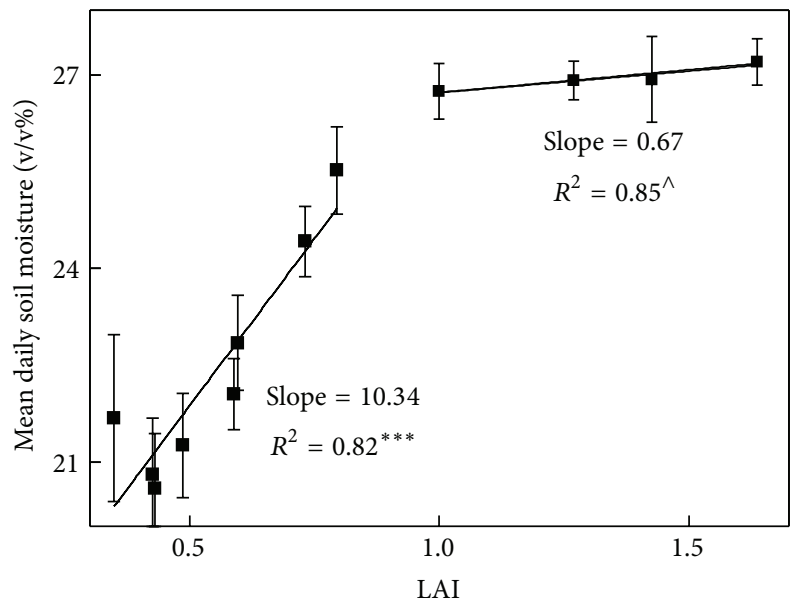

(e)

FIGURE 7: Relationships between mean daily E/ET and mean daily (a) E, (b) T, (c) LAI, and (d) soil moisture and (e) the relationship between LAI and mean daily soil moisture. ${ }^{\wedge} P>0.05 ;{ }^{*} P<0.05 ;{ }^{* *} P<0.01 ;{ }^{* * *} P<0.001$. 


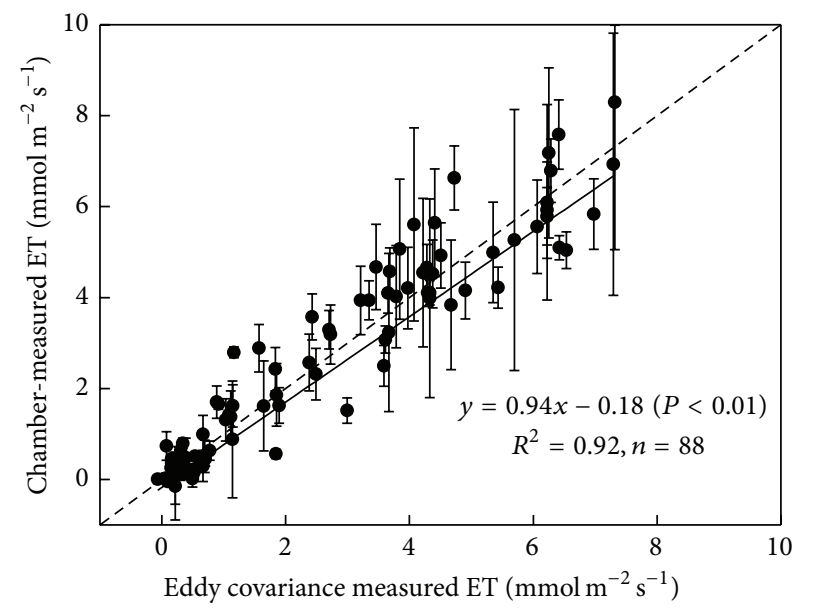

FIgURE 8: Comparison of the ecosystem vapor exchange (ET) obtained by the chamber method and the eddy covariance system. Data were obtained from the eddy covariance system located in the center of grazed grassland $(\mathrm{G})$.

Relative to grazed areas, grazer exclusion and cultivation both tended to increase ecosystem ET (Figure 4), which facilitates water transfer from the grassland to the atmosphere. Despite similar effects on ET, these two patterns of grassland use (GE, C) may have differing effects on regional climate. Elevated rates of ET would increase regional precipitation in both types of systems, but the larger mass of accumulated litter in grasslands with grazers excluded (Table 2) would increase rainfall absorption and infiltration, reducing water loss by overflow and evaporation. In contrast, without accumulated litter (Table 2), lower rainfall infiltration in cultivated steppe [8] would reduce ground water supplementation, and ground water may eventually be exhausted by elevated vapor loss (Figure 4). Thus, long-term cultivation of steppe may intensify drought and cause damage to regional ground water stores, whereas grazer exclusion may increase soil moisture content sustainably, with corresponding effects on regional climate through increased precipitation and humidity.

4.2. Factors Driving the Variation of Components of ET among Patterns of Grassland Use. In arid and semiarid areas, soil water content is a key factor controlling vapor loss [8, 23], and previous studies have shown that soil moisture is closely related to ET and E [20, 23, 31]. Similarly, in this study, variation in soil moisture among different land uses explained $90 \%$ and $89 \%$ of the mean daily ET (Figure 6(j)) and E (Figure 6(k)), respectively. Additionally, we found that soil moisture variation among patterns of grassland use may be caused by changes in LAI with land use (Table 2). This was demonstrated by strong positive relationships of LAI and soil moisture (Figure 7(e)), where LAI explained $95 \%$ of soil moisture variation, and may also underlie the close correlations of LAI with ET (Figure 6(d)) and E (Figure 6(e)). Furthermore, significant relationships of ET and $\mathrm{E}$ with aboveground biomass and soil bulk density may be because these community traits are inherently related to LAI (Figure 6). In contrast to previous work conducted on large spatial and temporal scales [26, 31], we found no significant relationships between LAI and T (Figure 6(f)). Comparison of these studies with our work and similar findings in an agricultural system [24] suggest that the influence of LAI on vapor consumption may vary with scale.

Few studies have been conducted on the daily dynamics and controlling factors of ecosystem ET and its components. At the large spatial and temporal scale, evidence suggests that change in ET may be closely related to some microclimate factors and soil traits, such as VPD, air temperature, soil temperature, and soil moisture [23, 26, 31]. Consistent with previous conclusions, we found that VPD and air temperature were significantly related to ET, E, and T (Figure 5). In particular, AT explained $80 \%$ of the variation in ET rates among varied land uses (Figure 5(a)). However, unlike previous studies $[23,31]$, changes in soil temperature and moisture were not correlated with $\mathrm{E}$ and $\mathrm{T}$ (Figure 5). Instead, we suggest that soil moisture may contribute to vapor exchange regulation indirectly. Since soil water supply ability varies with soil moisture, we assumed that soil moisture may be the primary factor controlling the regression slope of E and ET with AT and VPD under different grassland use patterns.

$\mathrm{E} / \mathrm{ET}$, the contribution of $\mathrm{E}$ (rather than $\mathrm{T}$ ) to total ecosystem vapor consumption (ET) $[24,38]$, is an important trait of water vapor exchange and the ecosystem in general [39]. Measurements of E/ET in this study (approximately 0.4, Figure 4) were comparable with those obtained by modeling [37] and experimental observation [31] in similar ecosystems. Variation in mean daily E (Figure 7(a)) and T (Figure 7(b)) both significantly affected E/ET, although E explained three times more variation in E/ET than T. Thus, variation in surface vapor consumption (E) was more important in controlling patterns of E/ET among grassland use types. Moreover, because soil moisture directly regulates E [10], soil moisture was also significantly positively related to E/ET (Figure $7(d)$ ). Finally, change in LAI with varying patterns of land use was a significant predictor of soil moisture (Figure 7(e)), which is similar to $\mathrm{Xu}$ et al.s result [32]. Consequently, LAI explained $81 \%$ of the variation in E/ET (Figure $7(\mathrm{c})$ ). These results corroborate the conclusions of a previous modeling study [26] that LAI is a primary community characteristic involved in regulation of the components of ecosystem ET.

\section{Conclusions}

Land use changes in grasslands of temperate steppe ecosystems, such as cultivation and grazing exclusion, may significantly influence vegetation and soil properties as well as some microclimate factors. Thus, variation in grassland use may have large effects on the vapor budget. Our results indicated that grassland cultivation and grazing exclusion both tend to increase ecosystem ET, with a significant increase in cultivated steppe. Differential litter accumulation and resultant infiltration of rainfall to ground water among grassland uses suggest that large-scale cultivation may intensify aridity of the 
steppe area in Northern China, while the grazing exclusion may gradually alleviate local arid conditions. Division of ET into its components indicated that changes in ET in cultivated and grazer excluded grassland were primarily caused by elevated $\mathrm{E}$, while $\mathrm{T}$ did not increase significantly. Through shading, variation in LAI with land use type substantially influenced the soil moisture, thus acting as a key regulator of E and even ET and E/ET in the ecosystem. Consequently, LAI is the primary regulating factor of the magnitude and composition of grassland-atmosphere vapor exchange under different grassland uses. These observed results would help reduce the uncertainty of relevant models in simulating ET and the surface energy budget and provide significant reference for the land use management to alleviate the climate change.

\section{Conflict of Interests}

The authors declare that there is no conflict of interests regarding the publication of this paper.

\section{Acknowledgments}

This research was jointly funded by the State Key Technologies R\&D Program (Grant no. 2013BAC03B04), the Natural Sciences Foundation of China (41301043), the Funding for Talent Young Scientists of IGSNRR (2013RC203), and the National “973" Project (no. 2010CB950902). In addition, the authors thank Dr. Ning Jia for her help in improving their figures, as well as the editor and two anonymous reviewers for their constructive comments, which helped them to improve the paper.

\section{References}

[1] S. Chen, J. Chen, G. Lin et al., "Energy balance and partition in Inner Mongolia steppe ecosystems with different land use types," Agricultural and Forest Meteorology, vol. 149, no. 11, pp. 1800-1809, 2009.

[2] IPCC, Climate Change 2007: The Physical Science Basis, Contribution of Working Group I to the Fourth Assessment Report of the Intergovernmental Panel on Climate Change, edited by S. Solomon, D. Qin, M. Manning, Z. Chen, M. Marquis, K. B. Averyt, M. Tignor and H. L. Mille, Cambridge University Press, Cambridge, UK, 2007.

[3] J. Liu, M. Liu, D. Zhuang, Z. Zhang, and X. Deng, "Study on spatial pattern of land-use change in China during 1995-2000," Science in China, Series D: Earth Sciences, vol. 46, no. 4, pp. 373384, 2003.

[4] Y.-Z. Li, J.-W. Fan, L.-X. Zhang, J. Di, G.-F. Liu, and J. Li, “The impact of different land use and management on community composition, species diversity and productivity in a typical temperate grassland," Acta Pratacultuae Sinica, vol. 22, no. 1, pp. $1-9,2013$.

[5] L. Jiyuan and B. Aoser, "Study on spatial-temporal feature of modern land use change in China: using remote sensing techniques," Quaternary Sciences, vol. 20, no. 3, pp. 229-239, 2000.

[6] W. Tao, "Land use and sandy desertification in the north China," Journal of Desert Research, vol. 20, no. 2, pp. 103-107, 2000.
[7] R. Lal, "Land use and soil management effects on soil organic matter dynamics on Alfisols in Western Nigeria," in Soil Processes and the Carbon Cycle, pp. 109-126, CRC Press, Boca Raton, Fla, USA, 1997.

[8] H. Miao, S. Chen, J. Chen et al., "Cultivation and grazing altered evapotranspiration and dynamics in Inner Mongolia steppes," Agricultural and Forest Meteorology, vol. 149, no. 11, pp. 18101819, 2009.

[9] J. M. Wraith, D. A. Johnson, R. J. Hanks, and D. V. Sisson, "Soil and plant water relations in a crested wheatgrass pasture: response to spring grazing by cattle," Oecologia, vol. 73, no. 4, pp. 573-578, 1987.

[10] W. Bai, S. Wan, S. Niu et al., "Increased temperature and precipitation interact to affect root production, mortality, and turnover in a temperate steppe: implications for ecosystem C cycling," Global Change Biology, vol. 16, no. 4, pp. 1306-1316, 2010.

[11] Y. Bai, J. Wu, Q. Xing et al., "Primary production and rain use efficiency across a precipitation gradient on the Mongolia plateau," Ecology, vol. 89, no. 8, pp. 2140-2153, 2008.

[12] L. A. Wever, L. B. Flanagan, and P. J. Carlson, "Seasonal and interannual variation in evapotranspiration, energy balance and surface conductance in a northern temperate grassland," Agricultural and Forest Meteorology, vol. 112, no. 1, pp. 31-49, 2002.

[13] D. D. Baldocchi, L. Xu, and N. Kiang, "How plant functionaltype, weather, seasonal drought, and soil physical properties alter water and energy fluxes of an oak-grass savanna and an annual grassland," Agricultural and Forest Meteorology, vol. 123, no. 1-2, pp. 13-39, 2004.

[14] D. J. Bremer, L. M. Auen, J. M. Ham, and C. E. Owensby, "Evapotranspiration in a prairie ecosystem: effects of grazing by cattle," Agronomy Journal, vol. 93, no. 2, pp. 338-348, 2001.

[15] D. G. Williams, W. Cable, K. Hultine et al., "Evapotranspiration components determined by stable isotope, sap flow and eddy covariance techniques," Agricultural and Forest Meteorology, vol. 125, no. 3-4, pp. 241-258, 2004.

[16] L. B. Hutley, A. P. O’Grady, and D. Eamus, "Monsoonal influences on evapotranspiration of savanna vegetation of northern Australia," Oecologia, vol. 126, no. 3, pp. 434-443, 2001.

[17] J. F. Reynolds, P. R. Kemp, and J. D. Tenhunen, "Effects of longterm rainfall variability on evapotranspiration and soil water distribution in the Chihuahuan Desert: a modeling analysis," Plant Ecology, vol. 150, no. 1-2, pp. 145-159, 2000.

[18] C. Liu, X. Zhang, and Y. Zhang, "Determination of daily evaporation and evapotranspiration of winter wheat and maize by large-scale weighing lysimeter and micro-lysimeter," Agricultural and Forest Meteorology, vol. 111, no. 2, pp. 109-120, 2002.

[19] D. D. Baldocchi, "Assessing the eddy covariance technique for evaluating carbon dioxide exchange rates of ecosystems: past, present and future," Global Change Biology, vol. 9, no. 4, pp. 479492, 2003.

[20] S. Chen, G. Lin, J. Huang, and G. D. Jenerette, "Dependence of carbon sequestration on the differential responses of ecosystem photosynthesis and respiration to rain pulses in a semiarid steppe," Global Change Biology, vol. 15, no. 10, pp. 2450-2461, 2009.

[21] R. L. Scott, T. E. Huxman, W. L. Cable, and W. E. Emmerich, "Partitioning of evapotranspiration and its relation to carbon dioxide exchange in a Chihuahuan Desert shrubland," Hydrological Processes, vol. 20, no. 15, pp. 3227-3243, 2006. 
[22] L. B. Flanagan, E. J. Sharp, and M. G. Letts, "Response of plant biomass and soil respiration to experimental warming and precipitation manipulation in a Northern Great Plains grassland," Agricultural and Forest Meteorology, vol. 173, pp. 4052, 2013.

[23] S. Niu, X. Xing, Z. Zhang et al., "Water-use efficiency in response to climate change: from leaf to ecosystem in a temperate steppe," Global Change Biology, vol. 17, no. 2, pp.10731082, 2011.

[24] P. Béziat, V. Rivalland, T. Tallec et al., "Evaluation of a simple approach for crop evapotranspiration partitioning and analysis of the water budget distribution for several crop species," Agricultural and Forest Meteorology, vol. 177, pp. 46-56, 2013.

[25] D. Kool, N. Agam, N. Lazarovitch, J. L. Heitman, T. J. Sauer, and A. Ben-Gal, "A review of approaches for evapotranspiration partitioning," Agricultural and Forest Meteorology, vol. 184, pp. 56-70, 2014.

[26] Z. Hu, G. Yu, Y. Zhou et al., "Partitioning of evapotranspiration and its controls in four grassland ecosystems: application of a two-source model," Agricultural and Forest Meteorology, vol. 149, no. 9, pp. 1410-1420, 2009.

[27] P. Schönbach, H. Wan, M. Gierus et al., "Grassland responses to grazing: effects of grazing intensity and management system in an Inner Mongolian steppe ecosystem," Plant and Soil, vol. 340, no. 1-2, pp. 103-115, 2011.

[28] T. A. Day and J. K. Detling, "Water relations of Agropyron smithii and Bouteloua gracilis and community evapotranspiration following long-term grazing by prairie dogs," The American Midland Naturalist, vol. 132, no. 2, pp. 381-392, 1994.

[29] A. N. Nunes, A. C. de Almeida, and C. O. A. Coelho, "Impacts of land use and cover type on runoff and soil erosion in a marginal area of Portugal," Applied Geography, vol. 31, no. 2, pp. 687-699, 2011.

[30] F. Shi, H. Chen, Y. Wu, and N. Wu, "Effects of livestock exclusion on vegetation and soil properties under two topographic habitats in an alpine meadow on the eastern Qinghai-Tibetan Plateau," Polish Journal of Ecology, vol. 58, no. 1, pp. 125-133, 2010.

[31] S. Niu, M. Wu, Y. Han, J. Xia, L. Li, and S. Wan, "Water-mediated responses of ecosystem carbon fluxes to climatic change in a temperate steppe," New Phytologist, vol. 177, no. 1, pp. 209-219, 2008.

[32] X. Xu, R. A. Sherry, S. Niu, D. Li, and Y. Luo, "Net primary productivity and rain-use efficiency as affected by warming, altered precipitation, and clipping in a mixed-grass prairie," Global Change Biology, vol. 19, no. 9, pp. 2753-2764, 2013.

[33] S. Niu, H. Yang, Z. Zhang et al., "Non-additive effects of water and nitrogen addition on ecosystem carbon exchange in a temperate steppe," Ecosystems, vol. 12, no. 6, pp. 915-926, 2009.

[34] T. F. Keenan, D. Y. Hollinger, G. Bohrer et al., "Increase in forest water-use efficiency as atmospheric carbon dioxide concentrations rise," Nature, vol. 499, no. 7458, pp. 324-327, 2013.

[35] T. E. Huxman, M. D. Smith, P. A. Fay et al., "Convergence across biomes to a common rain-use efficiency," Nature, vol. 429, no. 6992, pp. 651-654, 2004.

[36] A. K. Knapp and M. D. Smith, "Variation among biomes in temporal dynamics of aboveground primary production," Science, vol. 291, no. 5503, pp. 481-484, 2001.

[37] Z. Hu, G. Yu, Y. Fu et al., "Effects of vegetation control on ecosystem water use efficiency within and among four grassland ecosystems in China," Global Change Biology, vol. 14, no. 7, pp. 1609-1619, 2008.

[38] W. K. Lauenroth and J. B. Bradford, "Ecohydrology and the partitioning AET between transpiration and evaporation in a semiarid steppe," Ecosystems, vol. 9, no. 5, pp. 756-767, 2006.

[39] C. Brümmer, T. A. Black, R. S. Jassal et al., "How climate and vegetation type influence evapotranspiration and water use efficiency in Canadian forest, peatland and grassland ecosystems," Agricultural and Forest Meteorology, vol. 153, pp. 14-30, 2012. 

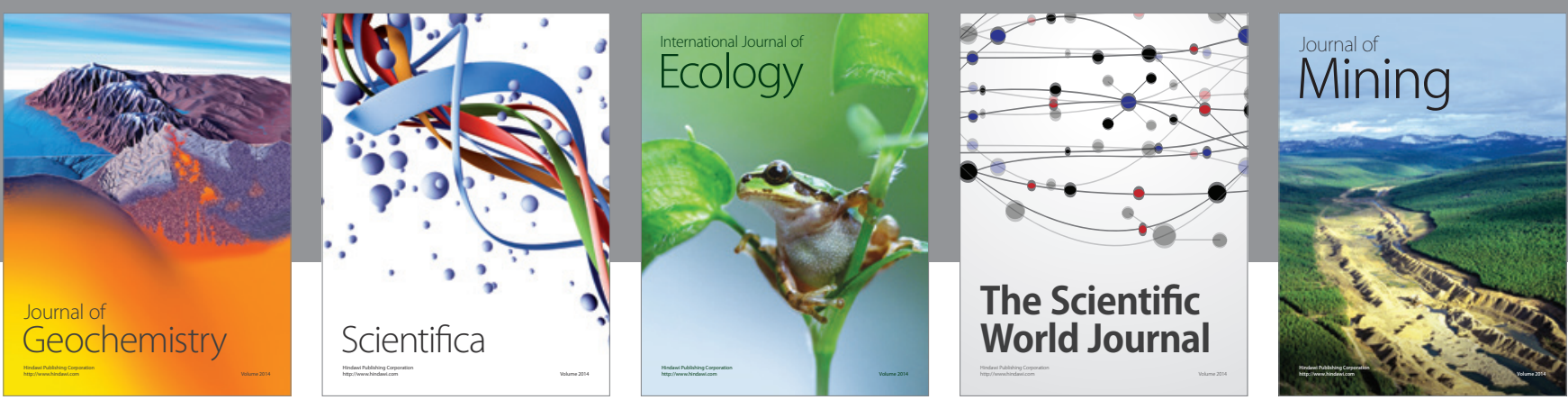

The Scientific World Journal
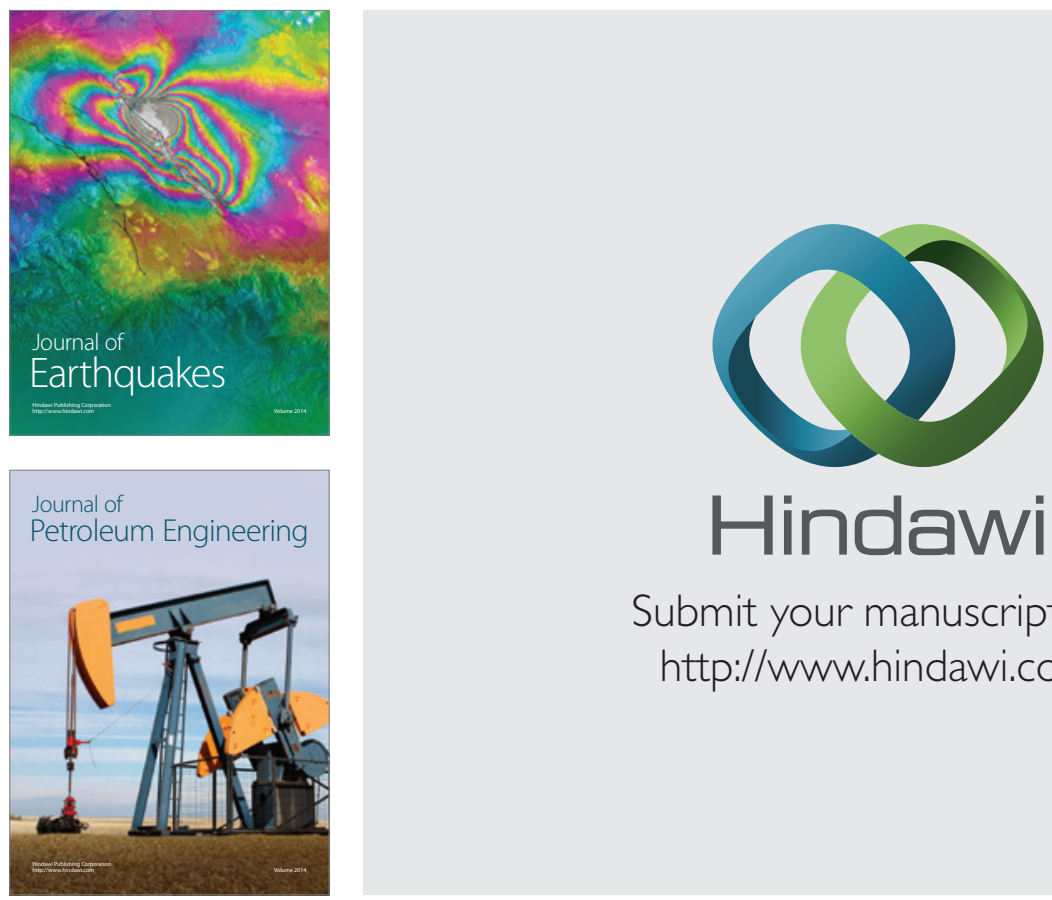

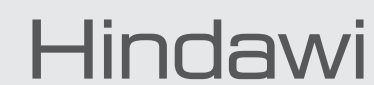

Submit your manuscripts at

http://www.hindawi.com
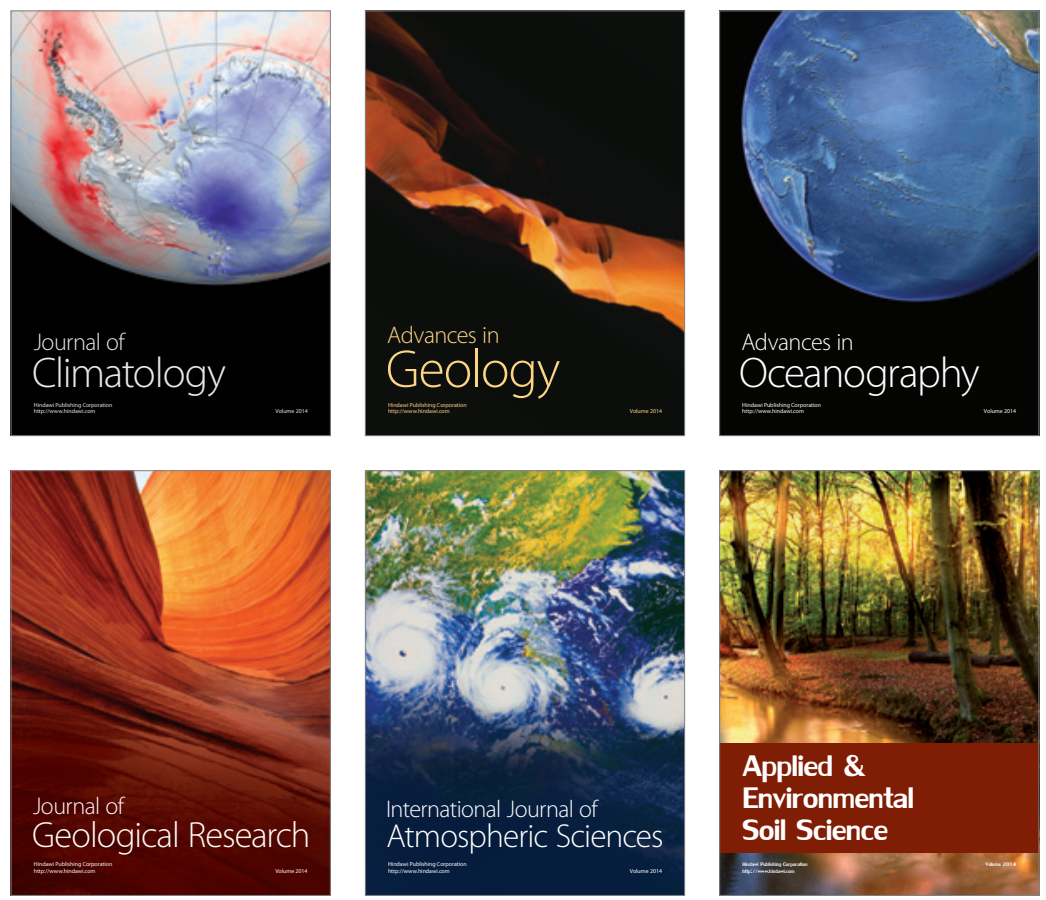
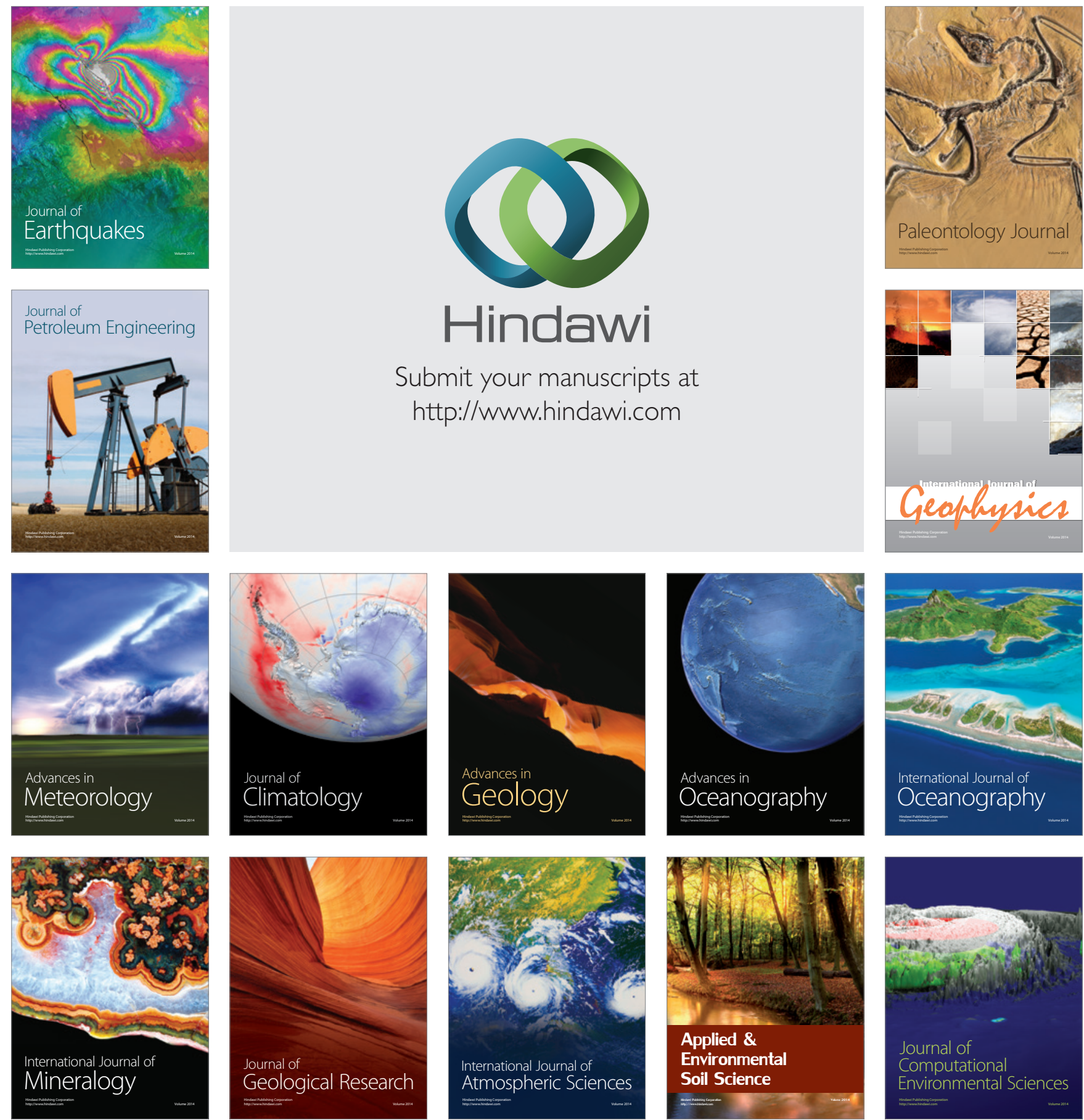